\title{
APPLYING A PERIPHERAL INJECTOR WATERFLOOD PATTERN FOR OIL RECOVERY. A CASE STUDY OF CARBONATE RESERVOIR
}

\author{
ПРИМЕНЕНИЕ СХЕМЫ ЗАВОДНЕНИЯ ПЕРИФЕРИЙНЫХ \\ ИНЖЕКТОРОВ ДЛЯ ДОБЫЧИ НЕФТИ. \\ ПРИМЕР КАРБОНАТНОГО КОЛЛЕКТОРА
}

\section{Rawand D. Abdulla Р. Д. Абдулла}

Ufa State Petroleum Technological University, Ufa, Russian Federation

Уфимский государственный нефтяной технический университет,

г. Уфа, Российская Федерация

\section{Ibragim I. Abyzbaev \\ И. И Абызбаев}

Ufa State Petroleum

Technological University,

Ufa, Russian Federation

Уфимский государственный нефтяной технический университет,

г. Уфа, Российская Федерация

The reservoir being studied is a tertiary reservoir of the Khabbaz oil field which is an Iraqi giant carbonate reservoir consisting mainly of limestone and dolomite rocks belonging to oligocene and miocene age with an average total thickness of about $150 \mathrm{~m}$ and an OIIP approximately 2109 MMSTB. Because of the limitation of the available injection water around the Khabbaz oil field, there is a need to optimize the use of this limited water resource through proper water flooding design and an efficient development scenario to achieve maximum oil recovery and the longest life cycle of this carbonate reservoir. In this study, based on the matched three-dimensional model simulation, a full-field development plan was drawn up for secondary recovery using conventional reservoir simulations for around 20 years to meet the strategic production requirements of the field operator. In order to provide additional support for water flooding patterns to maximize oil recovery from the reservoir under study, strategy is planned with the addition of 40 new ones Peripheral injectors along the periphery of reservoirs to flood patterns with the maintenance of a plateau of field production and number of pattern flood producers. The results of the feasibility analysis show that the addition of outlying wells is an unfeasible choice because the ultimate oil recovery generates relatively little profit of about $1.919 \%$, by exploiting a large amount of water injected into these new water wells that required additional expenses and additional water resources for injection purposes that are not available.

Изучаемый резервуар представляет собой третичный резервуар нефтяного месторождения Хаббаз, который представляет собой иракский гигантский карбонатный резервуар, состоящий в основном из известняков и доломитовых пород, принадлежащих к олигоцену и миоцену, со средней общей мощностью около 150 м и ОIIP примерно 2109 MMSTB. Из-за ограниченности доступной закачиваемой воды вокруг нефтяного месторождения Хаббаз существует необходимость оптимизировать использование этого ограниченного водного ресурса за счет правильного проектирования заводнения и эффективного сценария разработки для достижения максимального извлечения нефти и самого длительного жизненного цикла этого месторождения. В этом исследовании, основанном на моделировании подобранной трехмерной модели, был составлен план разработки всего месторождения для вторичной добычи с использованием обычного моделирования коллектора в течение примерно 20 лет для удовлетворения стратегических производственных требований оператора месторождения. Чтобы обеспечить дополнительную под-

\author{
Hiwa H. Mohamed \\ X. Х. Мохамед \\ Ufa State Petroleum \\ Technological University, \\ Ufa, Russian Federation \\ Уфимский государственный \\ нефтяной технический \\ университет, \\ г. Уфа, Российская Федерация
}

\section{Key words}

carbonate reservoirs; peripheral water flood; injectors; oil recovery; development

\section{Ключевые слова}

карбонатные коллекторы; заводнение периферийной водой; нагнетатели; нефтеотдача; разработка 
держку схем заводнения для максимального увеличения нефтеотдачи из исследуемого пласта, планируется добавить 40 новых. Периферийные нагнетательные скважины по периферии пластов для схем заводнения с поддержанием плато добычи на месторождении и количество производителей шаблонных паводков. Результаты технико-экономического обоснования показывают, что добавление удаленных скважин является неосуществимым выбором, поскольку конечная нефтеотдача приносит относительно небольшую прибыль, около 1,919 процента, за счет использования большого количества воды, закачиваемой в эти новые водные скважины, что потребовало дополнительных затрат и дополнительных недоступные водные ресурсы для закачки.

\section{Introduction}

Hydrocarbon exploration and production require significant investment and risk. However, the aim of the industry is to develop ways to produce as much hydrocarbon from any field discovered to maximize return on investment. Consequently, an excellent development plan is essential to perform this particular objective. Such includes simulation model research of the reservoir, in which the reservoir performance is analyzed with various recovery strategies and production situations to define the optimal method for producing as much petroleum products as potential. This guides the design of the ground surface installations required to manage the fluids generated. Additionally, economic and uncertainty models examine the feasibility of the project.

The simulation analysis is brought out using a reservoir model. The static model produces a reservoir replica as it's in a static state. The reservoir model consists of shape and petrophyscal properties such as saturation, permeability, porosity, contact fluids and faults. The flow properties and behavior of the reservoir are part of the dynamic model. The model includes a fluid model and the rock behavior of the reservoir, changing pressure from the fluid, the well model, the water influx model and other activities which actually affect the fluid flow from the ground to the surface [1]. It is worth noting that many uncertainties are involved in the simulation because the reservoir is heterogeneous. The certain model designed to simulate reservoirs therefore recognizes this as the reservoir's representation.

Carbonate reservoirs are of great economic importance in the petroleum industry around the world. Over half of the world's oil is found in carbonate reservoirs. These reservoirs are one of the most complex reservoirs to characterize and manage due to their high heterogeneity, which leads to more uncertainty in reigns at a distance from wells [2]. Conventional water flooding is the secondary recovery most widely used because water is widely available and cheap compared to other injected fluids, easy to inject and significantly efficient to displace oil [3].

The main objective of this study:

- the building a static and simulation dynamic reservoir model;

- using existing wells to use the models constructed for the reservoir primary recovery analysis;

- to design the optimal water flood strategy by the pattern waterflood and assess the viability of the application of the peripheral water flood to provide additional support for waterflood strategy to progress oil recovery in the carbonate reservoir with more water availability restrictions for injection purposes.

Brief Description of Reservoir under Study

It is one of Iraq three pay zone oil fields consisting of carbonate reservoirs. The oil field of Khabbaz is located in north-western Kirkuk, in Iraq, and about 12 kilometers from central Kirkuk as shown in Figure 1. In August 1976; the first KZ-1 well was drilled. Afterwards, many oil wells were drilled, and now the field has more than 40 oil wells. The $18 \mathrm{~km}$ length and $4 \mathrm{~km}$ width area is comprised of the anticline dome with northwestern-south-eastern axis and fault mainly the western flank. The lithology of the reservoir is mainly limestone, dolomite and some shale content. In this field there are three major petroleum reservoirs: Tertiary Reservoir, Cretaceous (Upper Qamchiq) Reservoir and Cretaceous (Lower Qamchiq) Reservoir. The objective of this study is to take the Tertiary Reservoir as a case study, and is considered to be an important reservoir in the Khabaz oil field containing five formations: Jeribe, Anah, Anah / Azkand, Azkand and Azkand / Ibraheem [4].

\section{Static Model}

The main purpose for building static model fit for the purpose is to catch the heterogeneity and irregularity within the reservoir to produce several crucial decisions that will assist in the 


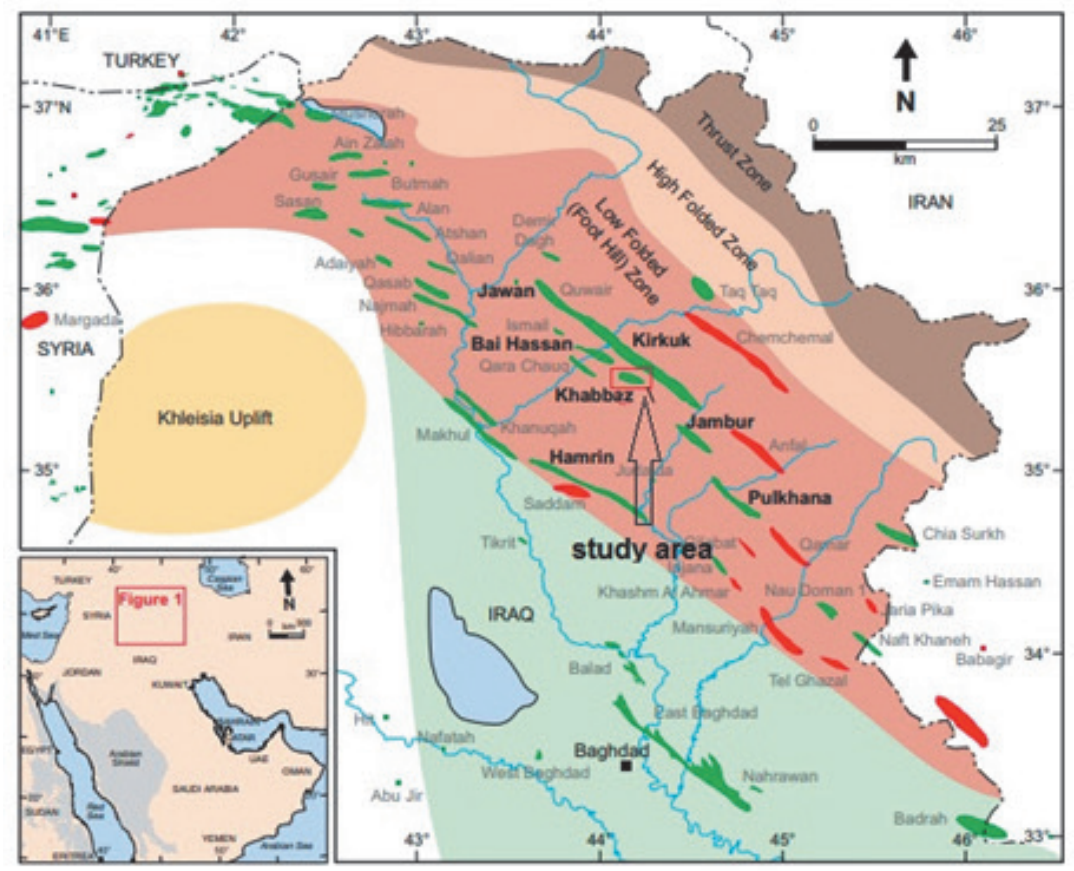

Figure 1. Location of Khabaz oil field

reservoir growth. It may be built model with a variety of statistical algorithms such as for the instance Gaussian Sequential Simulation, Gaussian Random, Cokriging and kriging etc.

Building a geological model fit for 3D purpose Based on a variety of factors such as: geological understanding of the location, deposition conditions within the reservoir. On the top and base surfaces of the procedure, a simple 3D grid consists of the top, middle and base skeleton of the reservoir [5]. This process leads to the formation of geological cells that supplement continuous properties (petrophysical).

A conceptual analysis of the observed data was developed using the information received. To distribute the data, they used a normal distribution.
The porosity model has been designed using the conceptual observed data analysis and the Gaussian sequential random function to add data.

\section{Pillar Gridding}

Gridding methods used in structural modeling consist of a 3D grid as a group of cubic cells deformed to fit horizons and aligned in pillars on faults to perform reservoir characterization 3D grid model for Tertiary reservoir using $(150 \times 150 \mathrm{~m})$ $\mathrm{X}, \mathrm{Y}$ increment pillar gridding to create $3 \mathrm{D}$ grid structure (Figure 2).

\section{Petro-Physical Model}

Porosity model

Porosity is a fundamental element of an oil reservoir this dictates the oil capability it can produce. Gaussian sequential Simulation

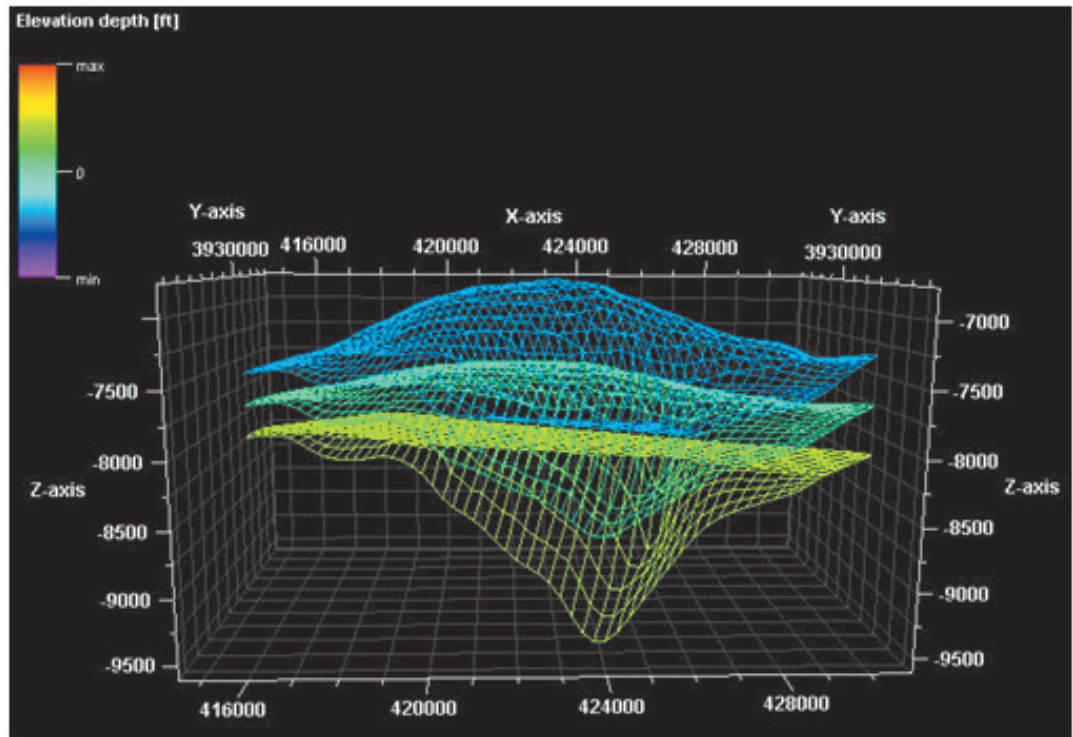

Figure 2. 3D grid skeletons of Tertiary reservoir 
algorithm was performed to interpolate wells so that porosity is distributed in every cell in 3D grids. The porosity modeling was built in step with the rock type model used as a guide for porosity distribution in each area [6]. The Porosity model shows that Azkand then Anna
Azkand is the high porosity zone. From statistical analysis, the typical porosity in the Azkand unit was about $17 \%$ and increased to reach range between $12-18 \%$ in the crust. Figure 3 shows porosity distribution in the Tertiary reservoir.

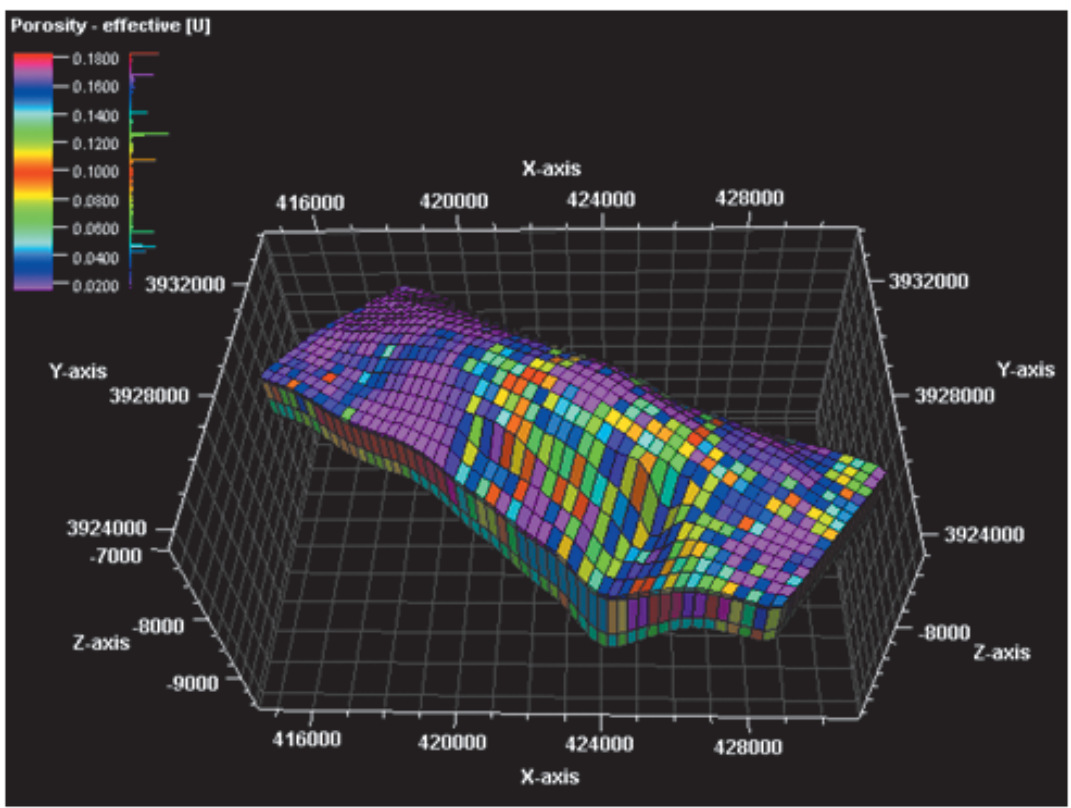

Figure 3. Porosity Model of the reservoir

\section{Permeability model}

Permeability is an important feature of a petroleum reservoir rock. It is a property of the pore medium which measures the formation capacity and ability for transmission of fluids. Rock permeability is very important because it controls the directional motion and the flow rate of forming liquids of the reservoir [7]. The permeability model distribution was created through the Gaussian sequential simulation and connected to the rock model in each zone within the static model. The Permeability model shows the most permeable zone in the Tertiary reservoir. The permeability was about $70 \mathrm{mD}$ and increased in some regions to vary between (30-91) $\mathrm{mD}$. Figure 4 shows permeability distribution in the Tertiary reservoir.

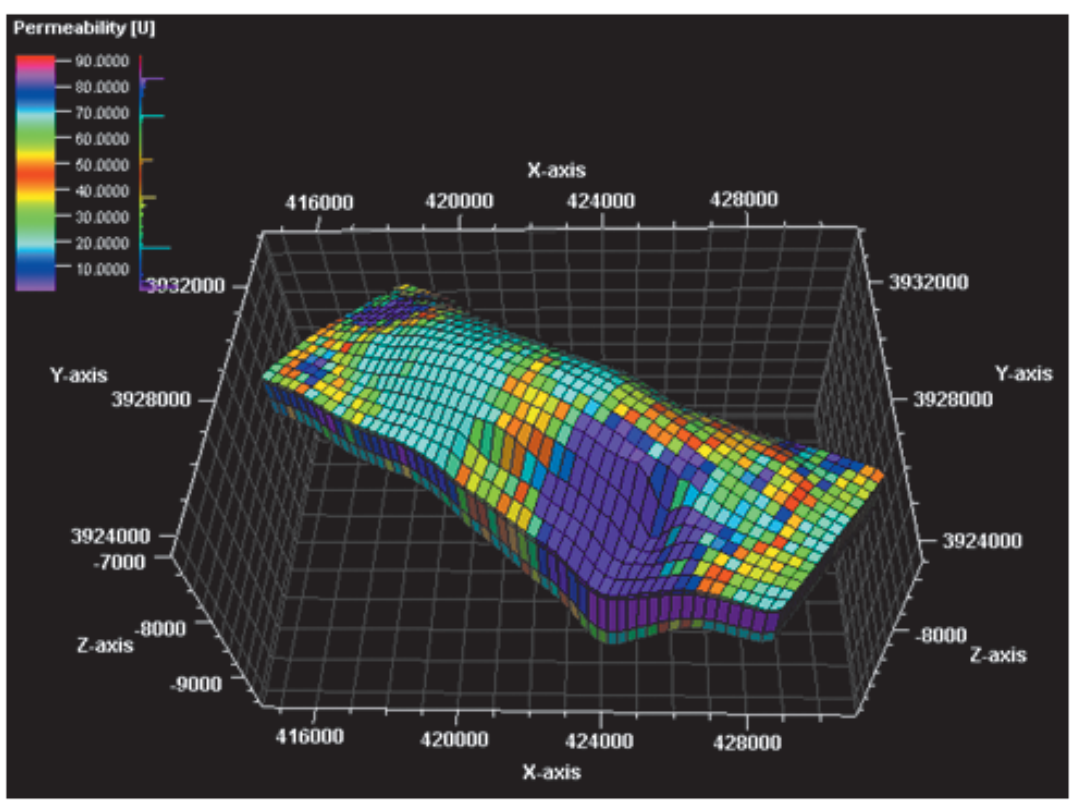

Figure 4. Permeability model of the reservoir 


\section{Water saturation model}

The saturation water model was built in step with the water saturation logs calculated. Statistical sequence Gaussian statistical methodology Gaussian simulation algorithm was used. The comparison between Tertiary reservoir zones in the water saturation model shows that the foremost useful geostatistic hydrocarbon accumulation distributed in Azkand formation particularly with in the crust where water saturation rang was between $4-18 \%$. Figure 5 shows the water saturation through the Tertiary reservoir.

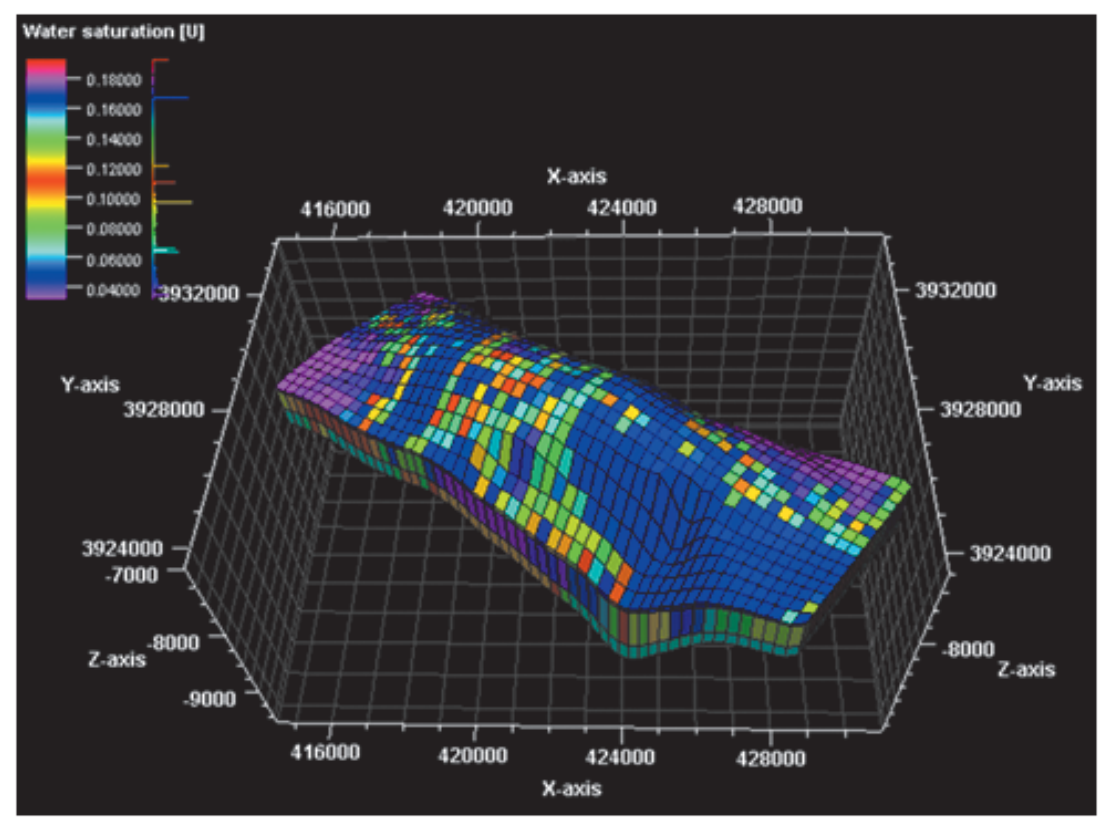

Figure 5. Water saturation model of the reservoir

\section{Dynamic modeling}

Before building a model of simulation, the geological model upscaling the process was implemented in order to minimize runtime in a dynamic simulation model with the high reservoir heterogeneity almost preserved [8]. This model is designed to simulate fluid flow through the reservoir for about 20 years in production history.

The PVT model is designed to represent the vertical variation of the oil properties and the physical properties of rock fluid in this model. The tertiary reservoir consists of an equilibration region, which is consistent with the fluid model and pressure system of the reservoir Tertiary. The reservoir initial pressure is 3335 psi at a 1990 MBSL datum depth and oil water contact is at $2050 \mathrm{~m}$ below sea level. The resulting Fluid contact in Tertiary reservoir and the initial pressure are shown in Figures 6 and 7.

In the form of well modeling in the model of simulation, there were approximately 21 wells of various types (vertical, linear, horizontal and multilateral) drilled and completed years ago in the Tertiary reservoir. For well completion modeling, in the simulation model, different types of well completion are used. Vertical and deviated wells with the cast hole are completed perforating completion of one or more layers. This dynamic estimates the oil initially in place Model is very close to this through initialization Estimated difference $<1 \%$ in the geocellular model.

In addition, a history of the matching process for both individual wells and the entire reservoir is achieved through validation of the dynamic model

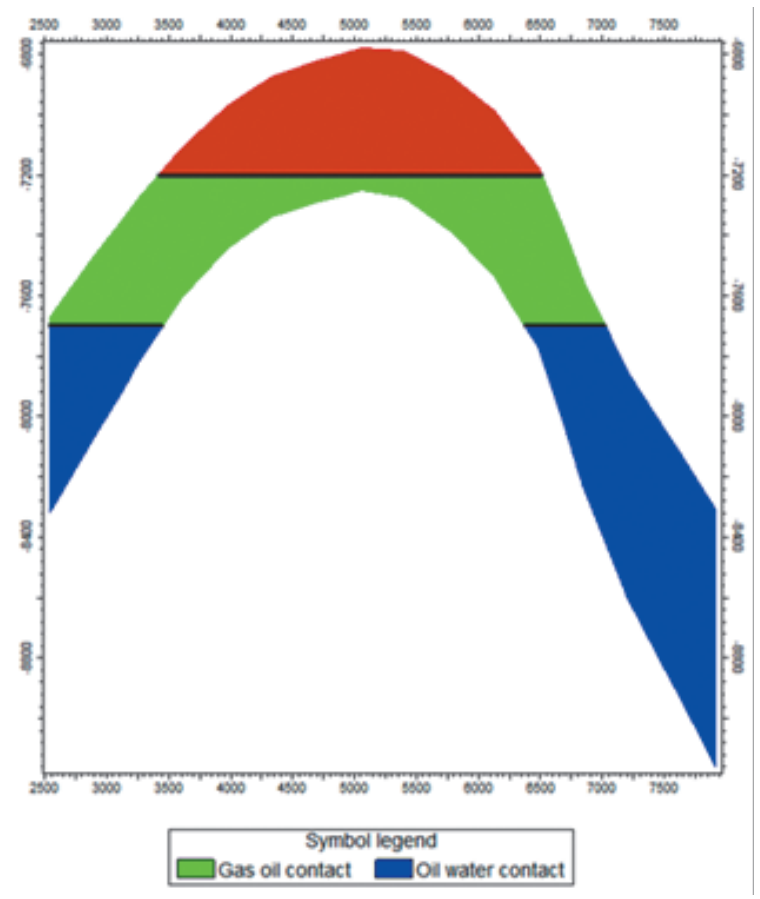

Figure 6. Fluid contact in Tertiary reservoir 
in terms of the oil production rate, the water injection rate, produced water cuts, and static pressure throughout the entire simulation time. In general, the historical results of the matching results were highly acceptable, with very good trends over the whole reservoir and the majority of reservoir wells over the entire dynamic simulation period. This model can therefore be used to realize the reservoir performance under the water flooding and other strategies in the future.
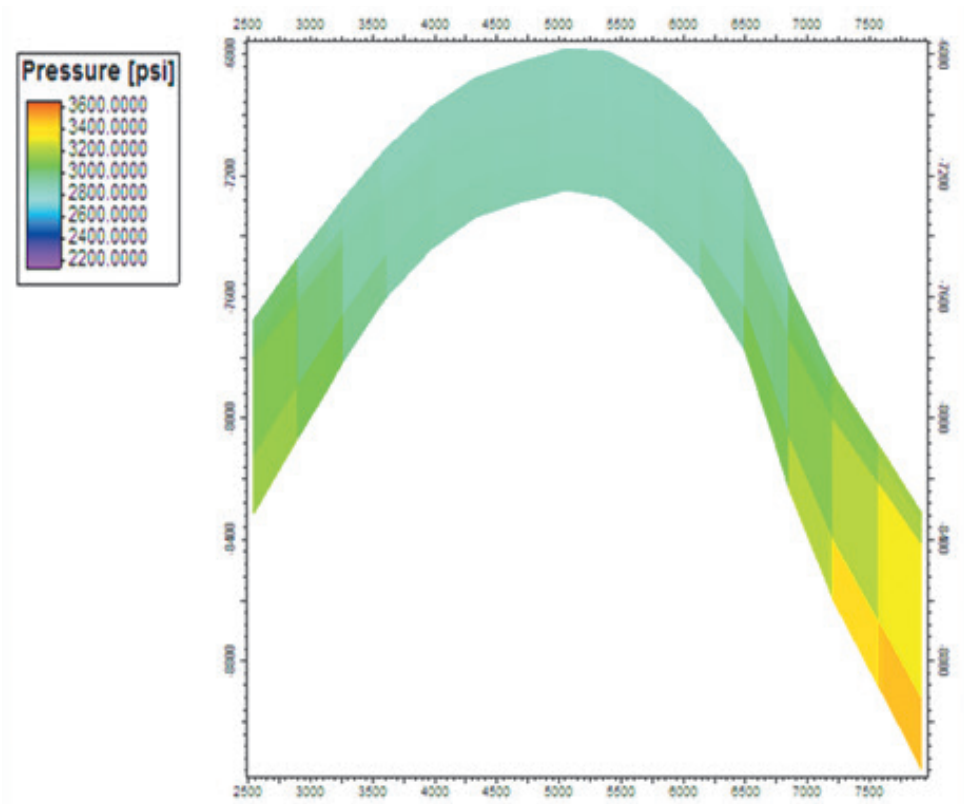

Figure 7. Vertical distribution of tertiary initial reservoir pressure

\section{Development plan}

For future prediction performance with a time period of approximately 20 years, development strategies under full-field water flooding would be suggested extending June 2017 to June 2040 in correspondence with the existing field conditions. This strategist drills more vertical injectors and gradually converts some of the existing production wells into injectors. The optimal development strategy of the reservoir under study should be chosen to achieve a reasonable production plateau period, optimum oil recovery and delay of the water breakthrough as much as possible, as well as optimum water injection volume due to some restrictions on the availability of water injected around the field.

The studied cases were:

- Case 1: Base case for the present wells and surface facilities presume basic therapeutic works are being done.

- Case 2: Pattern water flood plus peripheral injectors.

Case 1-Base Case

In the base case, the production rate of the reservoir starts with $40000 \mathrm{STB} / \mathrm{D}$ in 2020 and decline to $8461 \mathrm{STB} / \mathrm{D}$ at the end of 2040 because of some wells are closed, as results of the water cut approach $90 \%$ at the maximum acceptable production rate for these wells and GOR of 12 $\mathrm{MSCF} / \mathrm{STB}$. The average reservoir pressure in this case is approximately stable along the prediction period at $2420 \mathrm{psi}$ and GOR is stable at about 9.48 $\mathrm{MSCF} / \mathrm{STB}$. The water cut was increased through this case to $0.25 \mathrm{STB} / \mathrm{STB}$ at the end of the prediction period with a cumulative oil production of 174026987 STB and a recovery factor of $8.25 \%$ for the reservoir at the case end. All the results of this case are shown in Figures 8-10.

\section{Case 2 - Peripheral Water Injection Pattern}

In peripheral floods, the injection wells are on the outskirts and circumstances of a reservoir. The water injector wells should be drilled in or is close to the aquifer-reservoir interface displacing oil towards the producers as shown within the anticlinal reservoir of Figure 11, therefore the geometrical well configuration during this case as same as a ring of injectors surrounding the producers [9]. In this case, the limit oil rate plateau of the reservoir is 40000 $\mathrm{STB} / \mathrm{d}$. in this case is required to do work for adding 20 injection wells and do work for three production wells to convert in to injection wells. Field oil production rate, field pressure, field water cut, field GOR and accumulative water injected are shown in Figures 12-14 respectively. 


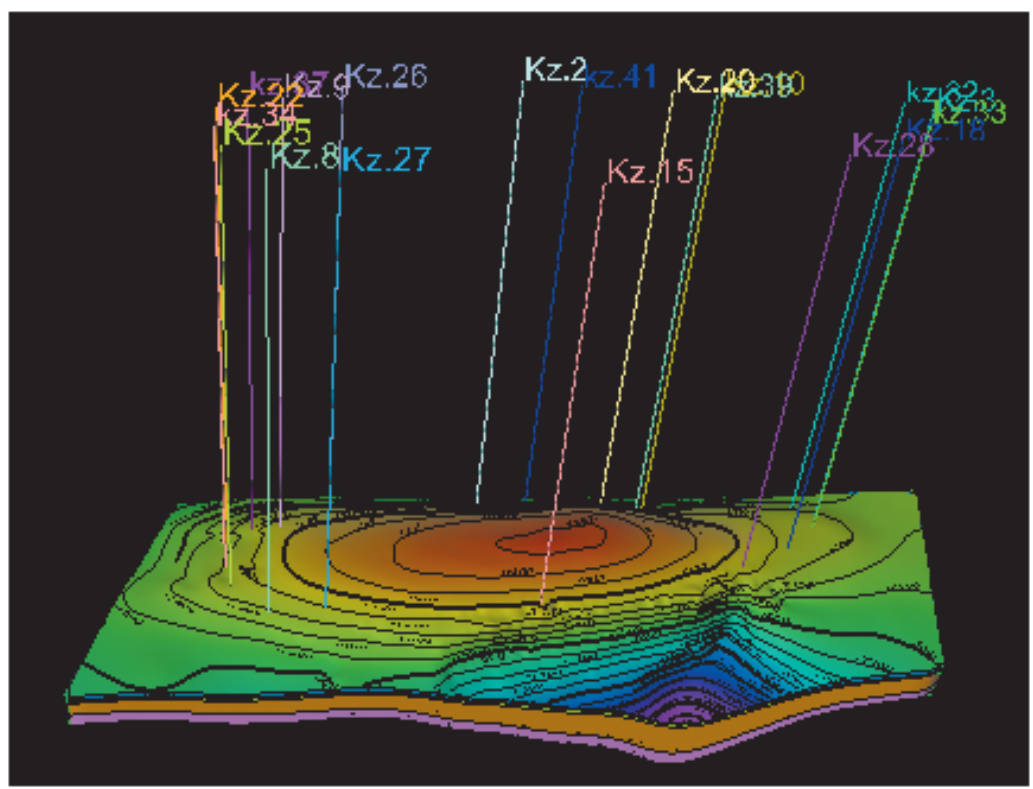

Figure 8. Production wells in Tertiary reservoir

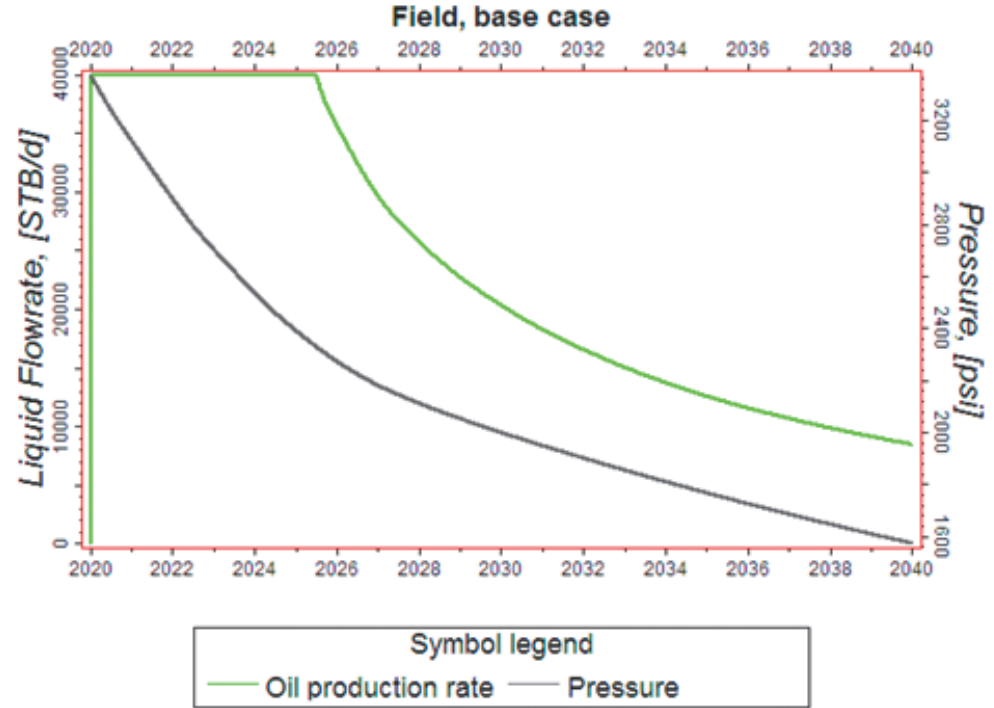

Figure 9. Field oil production rate and pressure results of base case

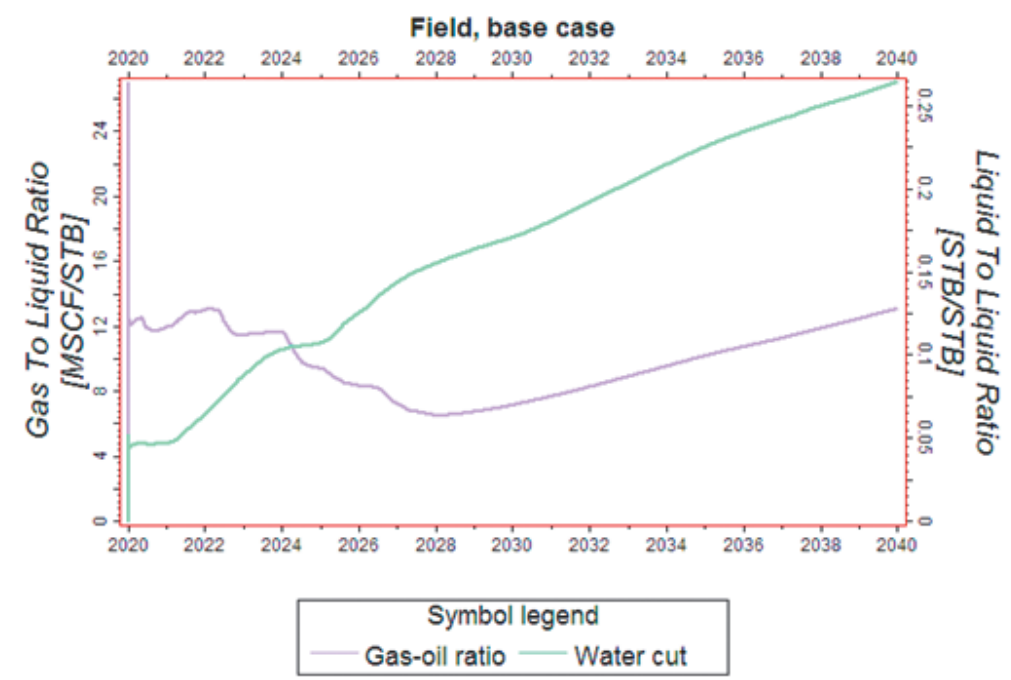

Figure 10. Field water cut and GOR results of base case 


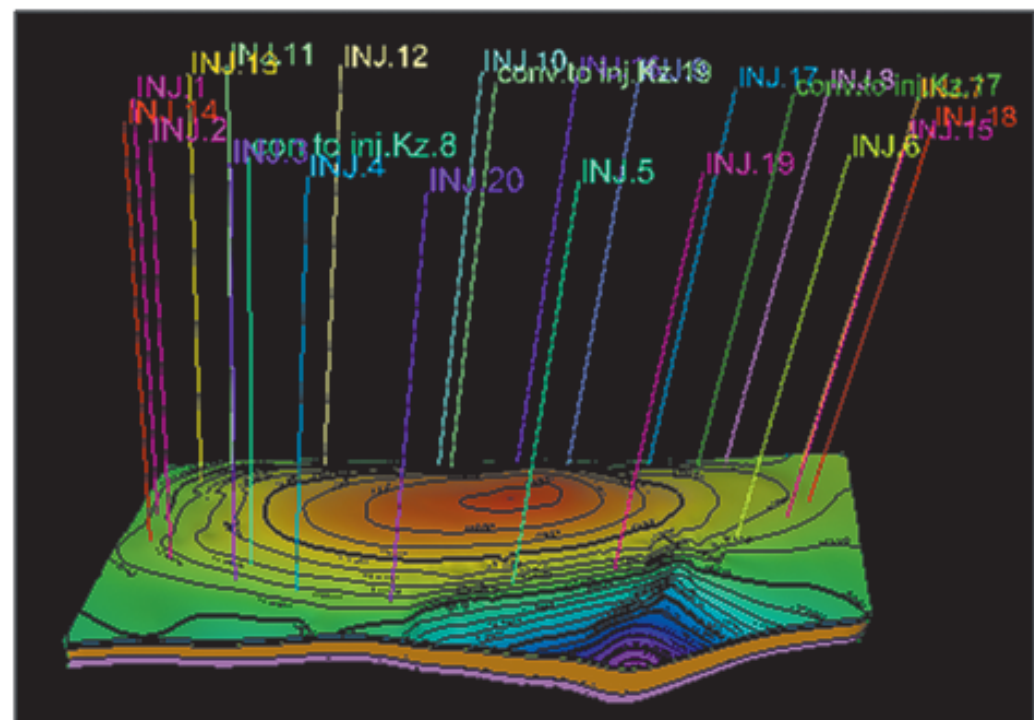

Figure 11. Designing peripheral water injection pattern in this study

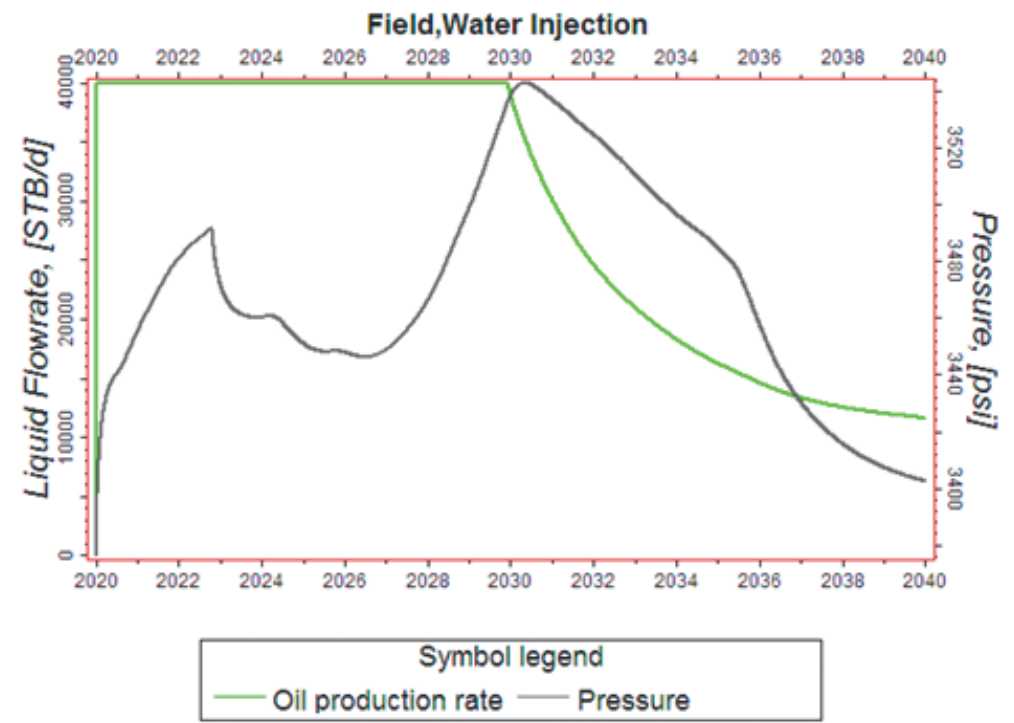

Figure 12. Field oil production rate and pressure results of Peripheral Water Injection Pattern

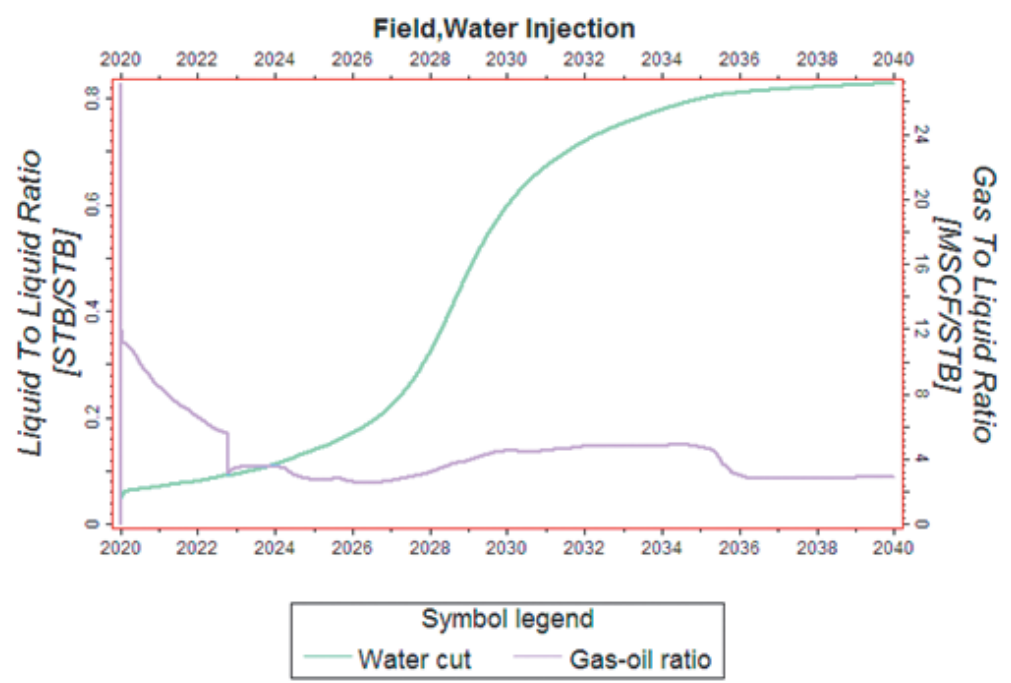

Figure 13. Field water cut and GOR results of Peripheral Water Injection Pattern 


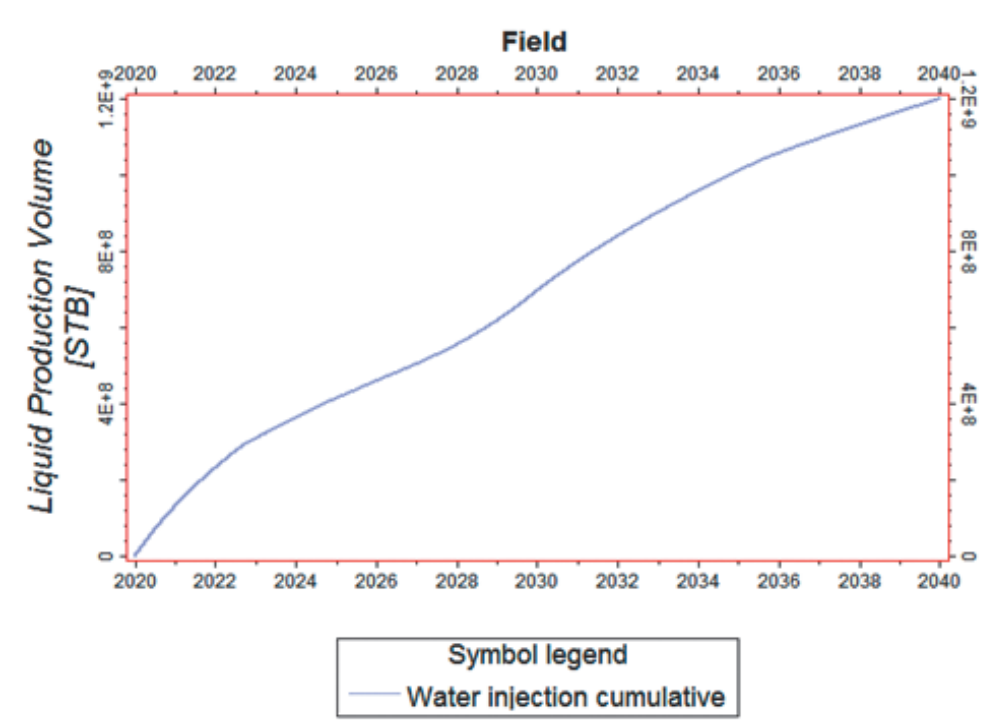

Figure 14. Field cumulative water injected

\section{Results and Discussion}

The results of two cases for the application of a base scenario and peripheral water floods in the tertiary reservoir are analyzed and studied in depth to assess the feasibility of using an additional sustenance to design water floods to maintain pressure and improve oil recovery. Hence, the results of case1 Base Scenario are compared with the results of Case 2 Pattern water flood plus peripheral injectors which includes the new peripheral injection wells. This comparison will be done by a plotting oil production rate, gas oil ratio, water cut, cumulative oil production are shown in Figures 15-18.

Table 1 shows for each planned case cumulative oil production after 20 years and the duration of the production plateau, as well as the Cumulative Water Injected, Field Pressure, Field Water Cut, Field Gas Oil Ratio and Field Recovery Factor at the end of the forecast cycle for both cases $1 \& 2$ and their differences (Table 1).

Table 1. Results from production prediction with peripheral waterflooding for 20 years

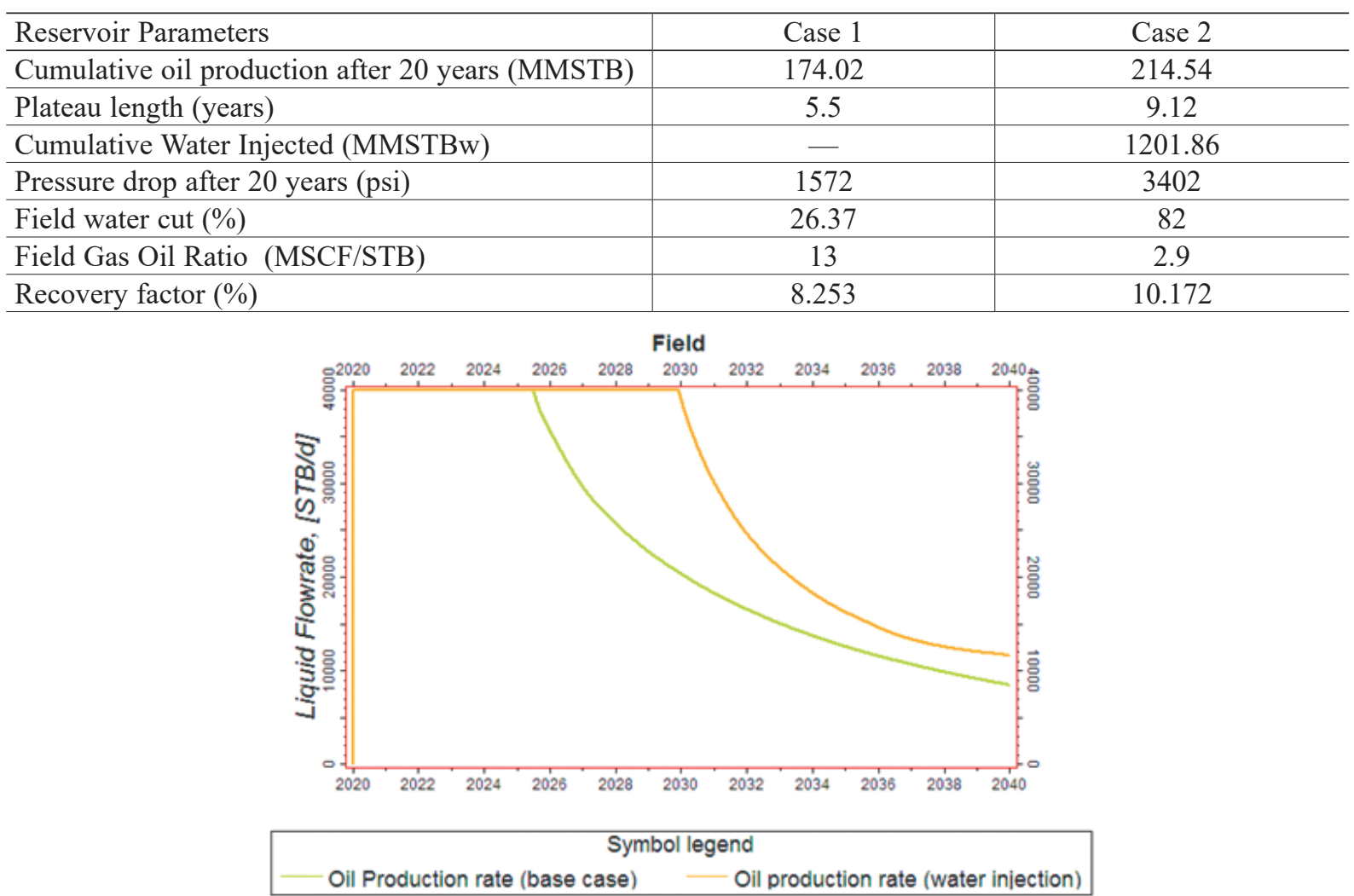

Figure 15. Field oil production rate for two cases 


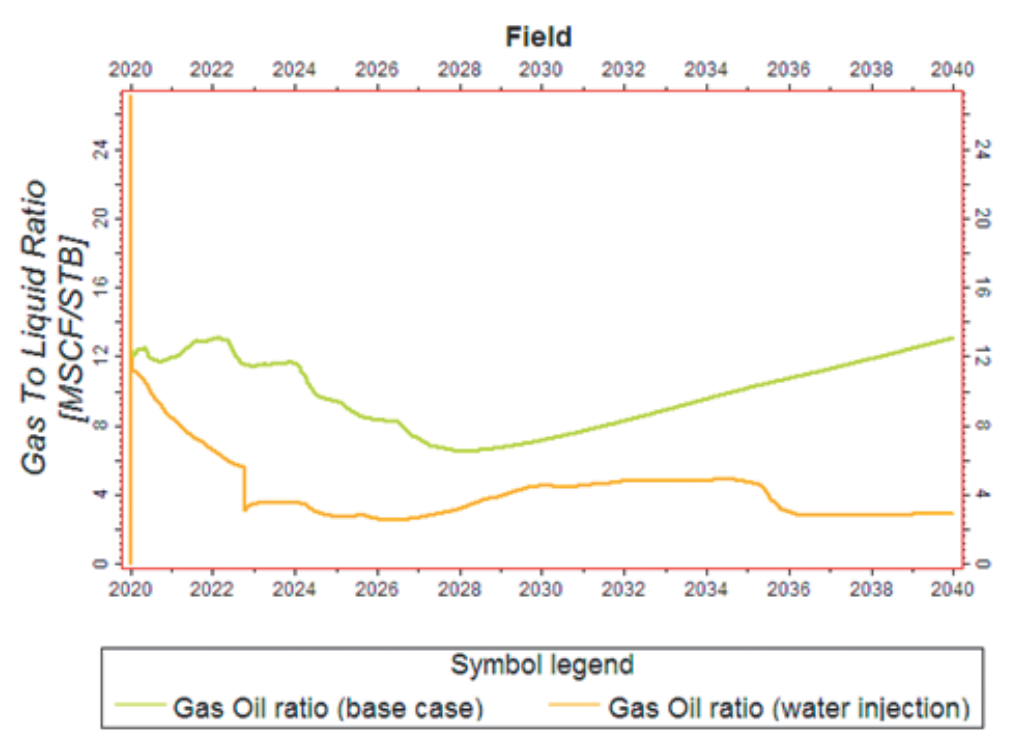

Figure 16. Field Gas Oil ratio for two cases

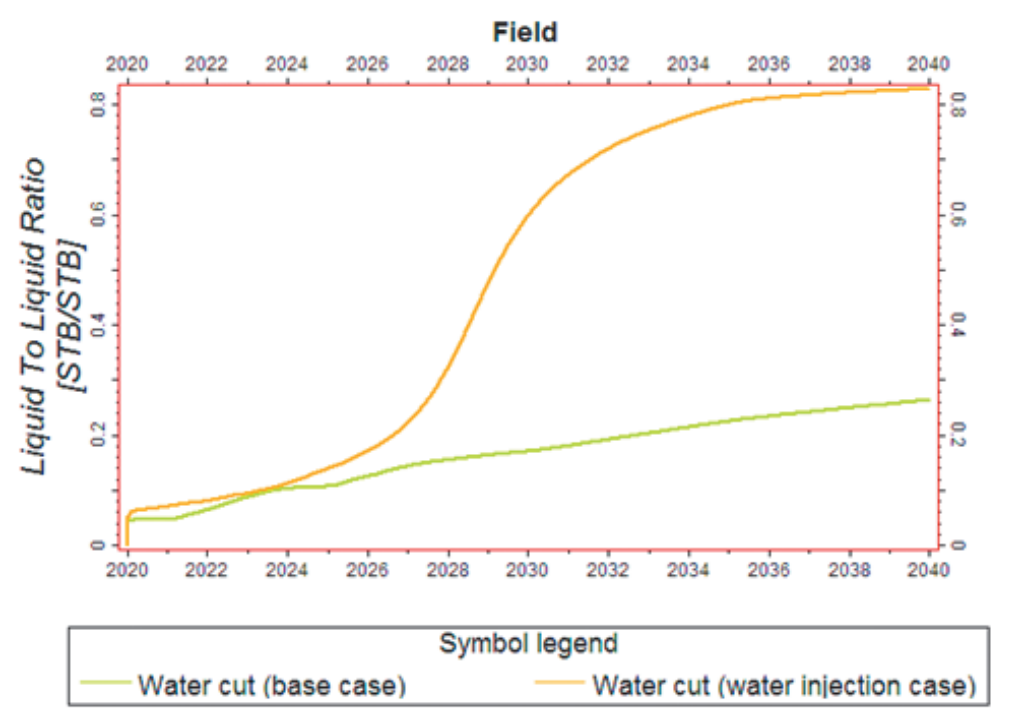

Figure 17. Field water cut for two cases

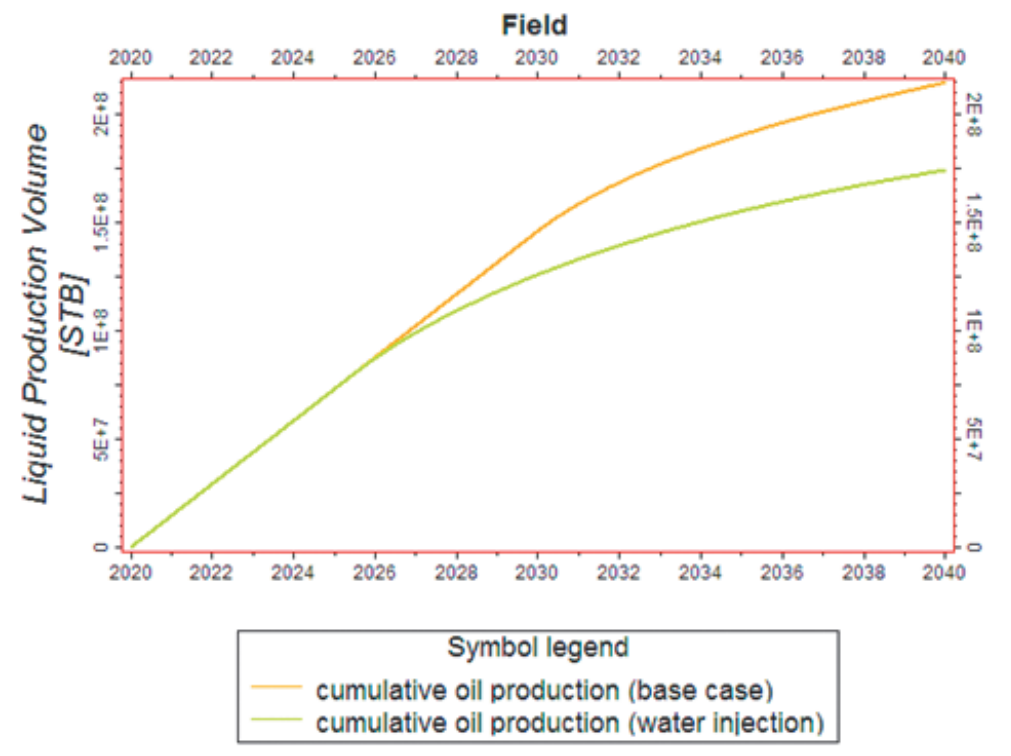

Figure 18. Field cumulative oil production for two cases 


\section{Conclusion}

The cumulative oil production was found to be 338 MMSTB with recovery factory $21 \%$ in the peripheral water injection. Regarding the introduction of peripheral injectors into water flood patterns, peripheral water floods are an unavailable strategy as an additional aid for water

\section{REFERENCES}

1. Ahmed T. Reservoir Engineering Handbook. New York, Gulf Professional Publishing, 2006. Third Ed. 1337 p.

2. Ahmed T. Reservoir Engineering Handbook. New York, Gulf Professional Publishing, 2010. Fourth Ed. 1463 p.

3. Chilingarian G.V., Robertson J.O., Kumar S. Carbonate Reservoir Characterization: a Geologic Engineering Analysis. Amsterdam, Elsevier Science Publishers B.V., 1992. 642 p.

4. Ma Y.Z. Quantitative Geosciences: Data Analytics, Geostatistics, Reservoir Characterization and Modeling. Denver, Springer Nature, 2019. First Ed. 644 p.

5. Wong P., Aminzadeh F., Nikravesh M. Soft Computing for Reservoir Characterization and Modeling. Heidelberg, Springer-Verlag Berlin Heidelberg GmbH, 2002. First Ed. 582 p.

6. Selley R.C., Sonnenberg S.A. Elements of Petroleum Geology. San Diego, Academic Press, 2014. Third Ed. 526 p.

7. Okotie S., Bibobra I. Reservoir Engineering: Fundamentals and Applications. Cham, Springer Nature, 2007. First Ed. 430 p.

8. Jassim S.Z., Goff J.C. Geology of Iraq. Brno, Dolin, Prague and Moravian Museum, 2006. First Ed. 486 p.

9. Lyons W.C., Pilsga G.J., Lorenz M.D. Standard Handbook of Petroleum and Natural Gas Engineering. Waltham, Gulf Professional Publishing, 2019. 1569 p. flood patterns to maintain pressure and enhance oil recovery. This strategy requires large amounts of water injected with small profits to increase the final oil recovery, extend the production plateau duration and increase reservoir pressure support due to the high tertiary reservoir heterogeneity.

\section{СПИСОК ИСПОЛЬЗУЕМЫХ ИСТОЧНИКОВ}

1. Ahmed T. Reservoir Engineering Handbook. New York: Gulf Professional Publishing, 2006. Third Ed. 1337 p.

2. Ahmed T. Reservoir Engineering Handbook. New York: Gulf Professional Publishing, 2010. Fourth Ed. 1463 p.

3. Chilingarian G.V., Robertson J.O., Kumar S. Carbonate Reservoir Characterization: a Geologic Engineering Analysis. Amsterdam: Elsevier Science Publishers B.V., 1992. 642 p.

4. Ma Y.Z. Quantitative Geosciences: Data Analytics, Geostatistics, Reservoir Characterization and Modeling. Denver: Springer Nature, 2019. First Ed. 644 p.

5. Wong P., Aminzadeh F., Nikravesh M. Soft Computing for Reservoir Characterization and Modeling. Heidelberg: Springer-Verlag Berlin Heidelberg GmbH, 2002. First Ed. 582 p.

6. Selley R.C., Sonnenberg S.A. Elements of Petroleum Geology. San Diego: Academic Press, 2014. Third Ed. 526 p.

7. Okotie S., Bibobra I. Reservoir Engineering: Fundamentals and Applications. Cham: Springer Nature, 2007. First Ed. 430 p.

8. Jassim S.Z., Goff J.C. Geology of Iraq. Brno: Dolin, Prague and Moravian Museum, 2006. First Ed. 486 p.

9. Lyons W.C., Pilsga G.J., Lorenz M.D. Standard Handbook of Petroleum and Natural Gas Engineering. Waltham: Gulf Professional Publishing, 2019. 1569 p.

\section{ABOUT THE AUTHORS}

СВЕДЕНИЯ ОБ АВТОРАХ

Абызбаев Ибрагим Измаилович, д-р техн. наук, профессор кафедры «Разработка и эксплуатачия нефтяных и газонефтяных месторождений», УГНТУ, г. Уфа, Российская Федерачия

Ibragim I. Abyzbaev, Doctor of Engineering Sciences, Professor of Oil and Gas \& Oil Field Development and Operation Department, USPTU, Ufa, Russian Federation

e-mail:shaura505@mail.ru

Абдулла Раванд Длиад, аспирант кафедры «Разработка и эксплуатачия нефтяных и газонефтяных месторождений», УГНТУ, г. Уфа, Российская Федераиия

Rawand D. Abdulla, Postgraduate Student of Oil and Gas \& Oil Field Development and Operation Department, USPTU, Ufa, Russian Federation

e-mail: rawandgeo18@gmail.com

Мохамед Хива Хамаамин, аспирант кафедры «Разработка и эксплуатачия нефтяных и газонефтяных месторождений», УГНТУ, г. Уфа, Российская Федераиия

Hiwa H. Mohamed, Postgraduate Student of Oil and Gas \&Oil Field Development and Operation Department, USPTU, Ufa, Russian Federation

e-mail:hiwa8@gmail.com 